\title{
THE DISTRIBUTION OF SODIUM AND CHLORIDE AND THE EXTRACELLULAR FLUID VOLUME IN THE RAT ${ }^{1}$
}

\author{
By DONALD B. CHEEK, CLARK D. WEST, AND CATHERINE CARTER GOLDEN \\ (From The Children's Hospital Research Foundation and Department of Pediatrics, University \\ of Cincinnati, Cincinnati, O.)
}

(Submitted for publication July 9, 1956; accepted October 17, 1956)

Our attempts to gain information concerning the amount of electrolyte in cell water and the theoretical concentration of intracellular cations necessarily revolve around our ability to partition total body water into extracellular and intracellular phases. The total body potassium, for example, is confined almost exclusively to the intracellular phase, and if the intracellular volume of the body could be defined, the net intracellular potassium concentration could be readily calculated as:

$$
\frac{\text { Total body } \mathrm{K}-\text { Extracellular } \mathrm{K}}{\text { Intracellular fluid volume }} \text {. }
$$

The most rational interpretation of extracellular fluid volume would seem to be that defined originally by Manery, Danielson, and Hastings (1), by Manery and Hastings (2) and later by Nichols, Nichols, Weil, and Wallace (3). These authors divide the extracellular fluid into the following components: the plasma water, the interstitial water, and the connective tissue water. The interstitial water is considered that volume of fluid which rapidly equilibrates with substances such as inulin. Connective tissue water is the volume of water which is principally associated with collagen and elastin, and with which substances such as inulin equilibrate slowly. The study of Nichols, Nichols, Weil, and Wallace (3) would indicate that the sum of these three phases of the extracellular fluid is defined reasonably well by the chloride space if correction of the chloride space is made for intracellular chloride, and for the slightly greater concentration of chloride in connective tissue water than is present in an ultrafiltrate of serum.

The major aim of the present study is to test

1 This investigation was supported in part by a research grant (H-1638) from the National Heart Institute, National Institutes of Health, United States Public Health Service. further the validity of the chloride space, corrected for the factors described above, as a measure of the extracellular volume by demonstrating an identity between it and the space calculated from the sodium content of extracellular fluid. Extracellular fluid volume has been calculated from sodium by the expression (extracellular sodium $) /(\mathrm{Na})_{\text {ef }}$ where extracellular sodium is the difference between total body sodium and the sodium which is not in the extracellular fluid (i.e., that in bone, cells, and within the lumen of the gastrointestinal tract) and $(\mathrm{Na})_{\text {ef }}$ is the sodium concentration of the serum ultrafiltrate.

Values for total body chloride and sodium on which the calculations depend have been obtained by carcass analysis of a large number of normal rats $(4,5)$. Values for bone sodium have been calculated from the $\mathrm{Na} / \mathrm{Ca}$ ratio for bone and from total body calcium. Values for cell sodium in muscle have been taken from data in the literature (6) calculated on the assumption that chloride in muscle occupies the same space as inulin and an exclusively extracellular position (7). Values for sodium in red cells were also calculated from the data of other investigators $(8,9)$ while those in visceral cells have been assessed by comparison of the volumes of distribution of inulin and sodium in the viscera following a constant infusion of inulin according to the technique described by Cotlove (7).

The good agreement between the sodium and chloride spaces calculated by correcting the value for total body electrolyte in this manner lends credence to the view that a value closely approximating the true extracellular volume of the rat has been determined. On this assumption the data obtained by carcass analysis have been used for further calculation of the intracellular volume and the theoretical concentrations of electrolyte within the cells. 


\section{METHODS AND CALCULATIONS}

The animals used in the study were male Wistar rats of the Hamilton Farms strain. For convenience and simplicity, a rat with a fat free dry solid content of 50 grams has been taken as a representative animal. Assuming a normal body fat content, such an animal would weigh approximately 220 grams.

Total body electrolyte and water. The carcass electrolyte and water content of the hypothetical $220-\mathrm{gm}$. rat was determined from regression equations calculated from data obtained by carcass analysis of 30 to 40 rats of normal health and vigor. The weight range of the animals was from 70 to $410 \mathrm{gm}$. with the greatest number falling around 220 grams $(4,5)$. The animals had been under observation at least two weeks prior to sacrifice and for ten days had been on a low residue diet of composition previously described (4). The regressions of total body electrolyte, water and nitrogen on fat free dry solid are given in Table I.

The methods of carcass analysis, with the exception of that for potassium, have been given previously $(4,5)$. In previous studies, potassium was determined on an acid extract of ashed carcass by flame photometry, while in the present study potassium in the ash has also been determined with chloroplatinic acid by the method of Consolazio and Talbott (10) modified to determine the salt $\mathrm{K}_{2} \mathrm{PtCl}_{6}$ gravimetrically instead of by iodometric titration. The method is to be published later in detail (11). The flame photometric method, employed on 47 animals, yielded a regression equation with a lower slope (0.283), a higher intercept $(+0.36)$ and a greater scatter of the data (standard error of the estimate, $1.08 \mathrm{mEq}$.) than the gravimetric procedure. For animals of a fat free dry solid content of $50 \mathrm{gm}$. with which the present paper is concerned, the two equations gave almost identical values. By the gravimetric procedure, carcass potassium would be $14.38 \mathrm{mEq}$. as compared with 14.51 by flame photometry.

Estimation of bone sodium. Bone sodium was estimated in five healthy male rats of 210 to $230-\mathrm{gm}$. weight. These animals were of the same strain and prepared in the same manner as those used for carcass analysis. After sacrifice and exsanguination, the carcass was dried at
100 to $105^{\circ} \mathrm{C}$ as previously described. After drying, the larger bones could be easily removed by pulling away the dried tissues and cutting free adherent cartilage. The bones were broken into small pieces, the fat extracted in a Soxhlet apparatus and the pieces further titrated to fine particles in a mortar. A portion of the particles were then ashed in a platinum crucible and the ash dissolved in $5.0 \mathrm{ml}$. of weak $\mathrm{HCl}$. Separate aliquots were taken for calcium determination by permanganate titration and for sodium determination by the gravimetric method of Butler and Tuthill (12). A separate aliquot of the bone particles was subjected to alkaline ashing and analyzed for chloride by the microdiffusion technique. The methods are identical to those used for carcass and are described in greater detail in previous papers $(4,5)$. The difficulties inherent in the flame photometric determination of bone sodium through interference by calcium (13) are obviated by use of the gravimetric procedure.

The sodium incorporated in bone salt was determined by subtracting from total bone sodium the amount of sodium calculated as present in the chloride space of bone. The total bone salt sodium of the carcass was calculated as total bone salt sodium

$$
=\frac{\text { bone salt sodium (mEq./100 gm. FFDS) }}{\text { bone calcium (mEq./100 gm. FFDS) }}
$$

Determination of total body collagen and of connective tissue chloride. Determinations of carcass collagen were performed on nine rats weighing approximately $220 \mathrm{gm}$., prepared before sacrifice in the same manner as those used for carcass analysis. The method of collagen estimation was that of Spencer, Morgulis, and Wilder (14). A homogeneous aliquot of powdered, fat free, dry carcass was autoclaved to convert collagen to gelatin, the gelatin was extracted with hot water and finally precipitated with tannic acid.

The chloride concentration of connective tissue water was determined by analysis of the achilles tendon of a normal rat and of a normal female mongrel dog. After exposure of the tendon, dissection was carried out rapidly, and each piece removed was immediately placed in a

TABLE I

\begin{tabular}{|c|c|c|c|}
\hline Regression equations & $\begin{array}{l}\text { Standard } \\
\text { error of } \\
\text { estimate }\end{array}$ & $\begin{array}{l}\text { Number } \\
\text { of } \\
\text { rats }\end{array}$ & 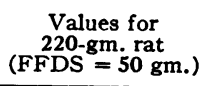 \\
\hline $\begin{array}{ll}\mathrm{Na}_{\mathrm{t}} \text { (mEq.) }=0.193 \text { FFDS }+0.78 \\
\mathrm{Cl}_{\mathrm{t}} \text { (mEq.) }=0.131 \text { FFDS }+1.04 \\
\mathrm{~K}_{\mathrm{t}} \text { (mEq.) }=0.323 \text { FFDS }-1.77 \\
\mathrm{Mg}_{\mathrm{t}} \text { (mEq.) }=0.1014 \text { FFDS }+0.594 \\
\mathrm{Ca}_{\mathrm{t}} \text { (mEq.) }=2.200 \text { FFDS }-1.74 \\
\mathrm{P}_{\mathrm{t}} \text { (mM) }=0.849 \text { FFDS }+0.300 \\
\mathrm{~N}_{\mathrm{t}} \text { (grams) }=0.131 \text { FFDS }-0.065 \\
\mathrm{H}_{2} \mathrm{O}_{\mathrm{t}} \text { (ml.) }=2.725 \text { FFDS }+13.19\end{array}$ & $\begin{array}{l} \pm 0.64 \mathrm{mEq} \\
\pm 0.41 \mathrm{mEq} \\
\pm 0.75 \mathrm{mEq} \\
\pm 0.32 \mathrm{mEq} \\
\pm 11.50 \mathrm{mEq} \\
\pm 3.20 \mathrm{mM} \\
\pm 0.200 \mathrm{gm} \\
\pm 3.70 \mathrm{ml}\end{array}$ & $\begin{array}{l}36 \\
35 \\
29 \\
32 \\
35 \\
30 \\
40 \\
36\end{array}$ & $\begin{array}{l}10.43 \mathrm{mEq} . \\
6.73 \mathrm{mEq} . \\
14.38 \mathrm{mEq} . \\
5.66 \mathrm{mEq} . \\
111.70 \mathrm{mEq} . \\
42.75 \mathrm{mM} \\
6.49 \mathrm{gm} . \\
149.40 \mathrm{ml} .\end{array}$ \\
\hline
\end{tabular}

Body composition in the normal rat (wt. range 70 to 410 grams): Regressions of total body electrolyte, nitrogen and water on fat free dry solid

Average fat content: $9.6 \%$ body wt. Range 15.3 to $3.3 \%$ 
separate tared stoppered weighing bottle to minimize evaporation of water. After weighing, the tendon was dried to constant weight at 100 to $105^{\circ} \mathrm{C}$, reweighed, ground in a mortar and fat extracted. Analyses for chloride, collagen and total nitrogen were carried out as for carcass $(4,5,14)$.

Determination of extracellular sodium and chloride of viscera. Using inulin as a reference substance, sodium and chloride were partitioned between extra and intracellular compartments in the lungs, trachea, esophagus, stomach, intestines and testes.by the method described by Cotlove for muscle (7). The data were obtained on 11 male rats whose weights ranged from 290 to $310 \mathrm{gm}$. The animals were placed on a low residue diet (4) four days before experimentation and fasted for 24 hours before sacrifice. Under ether anesthesia either a polyethylene catheter or a 22 gauge needle was placed in a tail vein for inulin infusion and the animal confined in the apparatus described by Kellogg, Burack, and Isselbacher (15). Following priming with an amount of inulin calculated as sufficient to raise the plasma inulin concentration to $300 \mathrm{mg}$. per cent, an infusion of inulin was maintained at a constant rate using an infusion machine. Both priming and maintenance solutions of inulin contained $7.5 \mathrm{gm}$. of inulin and $0.64 \mathrm{gm}$. of sodium chloride per $100 \mathrm{ml}$. After 6 hours of infusion in 7 animals and after 24 hours in 4 animals, ether anesthesia was again applied and the animal exsanguinated by aortic puncture. The infusion was stopped at the moment of aortic puncture. The lungs, gastrointestinal tract and testes were then quickly removed and placed in a tared vessel and weighed. Forty milliliters of water were then added and the tissues homogenized in a micro Waring blendor. The homogenate was placed in a boiling water bath for 30 minutes and then filtered. While in the water bath, the tubes were covered with aluminum foil to reduce evaporation. Serum and filtrate were analyzed for sodium by flame photometry and for inulin by the method of Schreiner (16) after preliminary hydrolysis with alkali as described by Ross and Mokotoff (17). Chloride in the tissue filtrate was determined by the micro diffusion technique of Conway $(4,18)$ and serum chloride by the method of Van Slyke (19). In early experiments the liver was analyzed separately, but the data are not included in the presentation because, after 24 hours of infusion, the inulin space was found to be larger than either the sodium or chloride space.

Inulinoid blanks were determined on the serum and filtrate of the visceral organs of 13 rats which received no inulin. These animals had been on the same diet as the experimental animals for four days before sacrifice and fasted for 24 hours before sacrifice. The inulinoid blanks for serum after alkali hydrolysis were found to be negligible and were disregarded. Blank values for the filtrate of viscera ranged from 2.4 to $4.7 \mathrm{mg}$. per cent. The average value was 3.44 and the standard deviation $\pm 0.52 \mathrm{mg}$. per cent. Inulin concentrations in the viscera filtrates of rats infused with inulin ranged from 25.4 to $56.8 \mathrm{mg}$. per cent with an average value of $38.0 \mathrm{mg}$. per cent. Serum inulin levels averaged 290 with a range from 209 to $428 \mathrm{mg}$. per cent. The total inulin and electrolyte content of the tissue was calculated as the product of viscera filtrate concentration times the volume of added water plus tissue water. Tissue water was taken as 81 per cent of wet weight (20).

The sodium and chloride spaces in viscera were corrected for the quantities of sodium or chloride present in the lumen of the gastrointestinal tract. The amount of the correction was determined by analysis of the luminal contents of five rats which had been on a low residue diet for four days and fasted for 24 hours before sacrifice. No infusion was given. After anesthetizing with ether, the lower end of the gastrointestinal tract was clamped, the gut dissected free and placed in a beaker. A rubber catheter was then inserted in the cardia of the stomach and $50 \mathrm{ml}$. of 5 per cent glucose in water rapidly injected so that the full length of the gut was distended. The clamp was then removed and the fluid gently pressed out through several incisions made in the gut wall. The whole procedure required only a few minutes. The volume of fluid was then measured and, after filtering, analyzed for sodium and chloride. The volume of fluid recovered averaged $49.6 \mathrm{ml}$.

Estimation of gastrointestinal fuid volume. The values for total body water determined by carcass analysis were corrected for the water contained within the gastrointestinal tract. The volume of fluid within the gut lumen was determined in six rats weighing approximately 220 grams. The animals were prepared in a manner identical to those subjected to carcass analysis; a low residue diet was fed for five days with free access to water. They were then sacrificed after a four-hour fast at the same time of day as the animals used for carcass analysis. The gastrointestinal tract was dissected free, placed on a board and opened longitudinally with scissors. The gut surface was then gently swabbed with gauze which had been previously dried by heating at $100^{\circ} \mathrm{C}$. The gauze was immediately placed in a weighing bottle, covered and weighed. The bottles were then uncovered, placed in an oven at $100^{\circ} \mathrm{C}$ for 24 hours and re-weighed. The water content of the gut in milliliters was taken as the weight difference of the gauze in grams.

Calculation of sodium, chloride, and inulin spaces. The volumes of distribution of sodium and chloride were calculated by dividing the amount of the ion present by the concentration in a serum ultrafiltrate. To determine serum ultrafiltrate concentration, the serum concentration was corrected for serum water and Donnan equilibrium as follows :

and

$$
(\mathrm{Na})_{\text {of }}=\frac{(\mathrm{Na})_{\mathrm{a}}}{0.93} \times 0.95
$$

$$
(\mathrm{Cl})_{\mathrm{ot}}=\frac{(\mathrm{Cl})_{\mathrm{s}}}{0.93} \times \frac{1}{0.95}
$$

in which $(\mathrm{Na})_{\text {of }}$ and $(\mathrm{Cl})_{\text {ef }}$ are the amounts of sodium and chloride per liter of serum ultrafiltrate, $(\mathrm{Na})$, and (C1). the amounts per liter of serum, and 0.95 the Don- 
nan factor. Serum water was taken as $930 \mathrm{ml}$. per liter of serum and is represented by the factor $\mathbf{0 . 9 3}$.

Serum ultrafiltrate concentrations of inulin were calculated as (In).$/ 0.93$ where 0.93 is again the serum water correction.

\section{RESULTS}

\section{Calculation of extracellular volume from extracel- lular chloride}

The total body chloride of a 220 -gram rat and the corrections necessary for the estimation of that portion of total chloride which is in extracellular fluid and at a concentration equal to that in a serum ultrafiltrate are given in Table II. A description of the calculation of these corrections follows.

Correction for connective tissue chloride. To correct total body chloride for the chloride in connective tissue in excess of that predicted from the chloride concentration of the serum ultrafiltrate, analyses of dog and rat tendon for water, chloride, collagen and total nitrogen were carried out. The data are given in Table III. In both species, the actual chloride content of tendon was $0.76 \mathrm{mEq}$. per $100 \mathrm{gm}$. of FFDS greater than would be predicted from the tendon water content and the serum ultrafiltrate chloride concentration. In terms

TABLE II

Calculation of extracellular fluid volume from extracellular chloride in a 220-gram rat (50 gram FFDS)

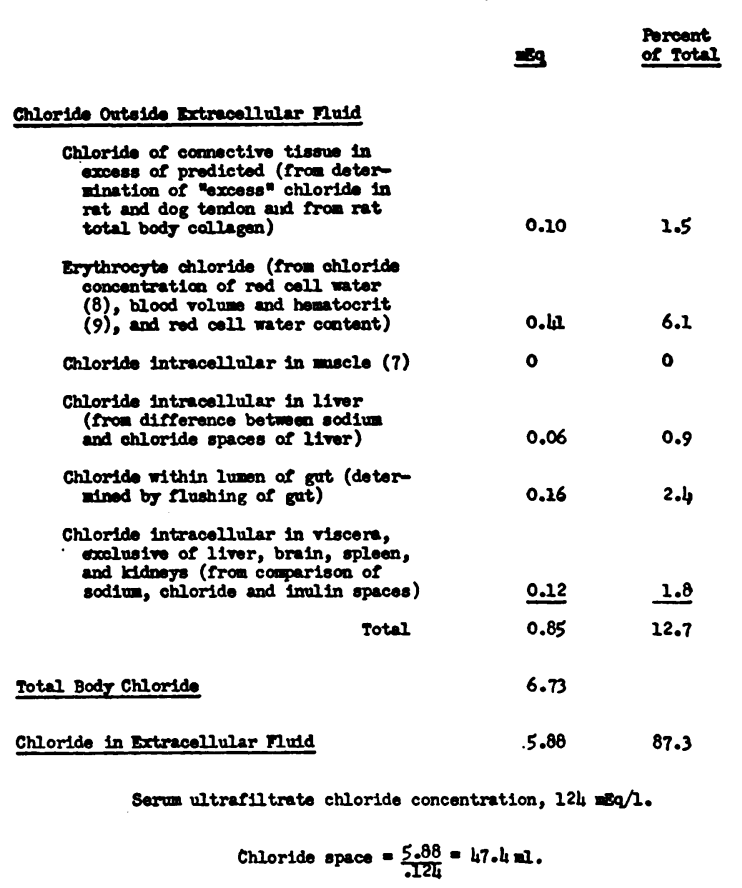

TABLE III

Chloride and water content of tendon in dog and rat: Calculation of "excess" chloride in tendon

\begin{tabular}{|c|c|c|c|c|c|}
\hline & $\begin{array}{c}(1) \\
\text { Tendon } \\
\text { water } \\
\text { ml. } 100 \\
\text { gm. FFDS }\end{array}$ & $\underset{m E q . / L .}{(\mathrm{Cl})_{\mathrm{er}}^{*}}$ & $\begin{array}{c}\text { (3) } \\
\text { Tendon Cl } \\
\text { predicted } \\
(1) \times \frac{(2)}{1,000} \\
m E q . / 100 \\
\text { gm. FFDS }\end{array}$ & $\begin{array}{c}(4) \\
\text { Tendon } \\
C l \\
\text { found } \\
m E q . / 100 \\
\text { gm.FFDS }\end{array}$ & $\begin{array}{c}\text { (5) } \\
\text { "Excess" } \\
\text { chloride } \\
\text { (4)-(3) } \\
\text { mEq.1100 } \\
\text { gm. FFDS }\end{array}$ \\
\hline $\begin{array}{l}\text { Dog } \\
\text { Rat }\end{array}$ & $\begin{array}{l}128 \\
140\end{array}$ & $\begin{array}{l}127 \\
125\end{array}$ & $\begin{array}{l}16.26 \\
17.50\end{array}$ & $\begin{array}{l}17.02 \\
18.26\end{array}$ & $\begin{array}{l}0.76 \\
0.76\end{array}$ \\
\hline
\end{tabular}

* $(\mathrm{Cl})_{\mathrm{of}}=$ Chloride concentration of serum ultrafiltrate.

of tendon water content, tendon chloride amounted to $133 \mathrm{mEq}$. per L. in the dog and $131 \mathrm{mEq}$. per L. in the rat; in both species the values were $6 \mathrm{mEq}$. per L. greater than the concentration of the serum ultrafiltrate.

Taking the excess chloride in connective tissue as $0.76 \mathrm{mEq}$. per $100 \mathrm{gm}$. of FFDS, the excess chloride associated with collagen in the whole rat may be calculated as $0.76 / 100 \times$ total body collagen (grams). Total body collagen in nine rats of approximately 220 grams body weight averaged $11.9 \pm 0.48$ (SD) grams. The excess chloride associated with connective tissue then becomes $0.10 \mathrm{mEq}$. The calculation assumes that all body collagen has the same affinity for chloride as does achilles tendon. No correction has been made for the fact that achilles tendon is not pure collagen; by analysis only 91 per cent of the total nitrogen of the tendon could be accounted for as collagen nitrogen.

Erythrocyte chloride. Calculation of the intracellular chloride of erythrocytes was made from the data of Bernstein (8) which give the chloride concentration of the rat red cell water, and from the data of Wang and Hegsted (9) which define the blood volume and hematocrit. According to the latter authors, the blood volume of a 220-gram rat closely approximates 7 per cent of the body weight and the hematocrit averages 45 . Red cell water was taken as 72 grams per $100 \mathrm{ml}$. and the chloride concentration of red cell water as 72 mEq. per L. (8). Using these values, the chloride intracellular in erythrocytes may be calculated as $1.86 \mathrm{mEq}$. per $\mathrm{Kg}$. of body weight. In a 220 -gram rat the value would be $0.41 \mathrm{mEq}$.

Chloride intracellular in muscle and liver. Based on the studies of Cotlove (7) comparing the distribution volumes of inulin and chloride in 
muscle after prolonged inulin infusion, the assumption has been made that chloride is not present in muscle cells. A similar assumption cannot be made for the liver. In this organ the volume of distribution of chloride exceeds that of sodium so that an intracellular position of chloride must be presumed. For lack of a better method, intracellular chloride in liver has been calculated on the assumption that the true extracellular volume of this organ is measured by the volume of distribution of sodium. In seven rats, the chloride space of liver exceeded the sodium space by 0.5 to $0.95 \mathrm{ml}$. corresponding to 0.066 to 0.120 $\mathrm{mEq}$. of chloride. The average value in the 300 gram rat of $0.088 \mathrm{mEq}$. of intracellular chloride becomes $0.060 \mathrm{mEq}$. for a 220 -gram rat.

Chloride within the lumen of the gastrointestinal tract. The chloride in the "transcellular" fluid within the gut was determined by flushing the intestinal tract with isotonic glucose solution. In five rats weighing approximately 300 grams, the chloride recovered averaged $0.22 \mathrm{mEq}$. and ranged from 0.14 to $0.28 \mathrm{mEq}$. Corrected to a body weight of 220 grams, the average value becomes $0.16 \mathrm{mEq}$. Several sources of error in this determination should be mentioned. Although the flushing procedure was carried out as rapidly as possible, the possibility cannot be excluded that some chloride diffused from the extracellular fluid through gut mucosa or serosa or through the incisions made in the gut wall. Also, the data were for use primarily in correcting the chloride space of viscera and to compare this space with the inulin space, as will be described below. Consequently the animals were not prepared in exactly the same manner as those used for carcass analysis. Food was withheld from those used for carcass analysis for only four hours while those used for the flushing procedure were starved for 24 hours. Although both groups had been on the same low residue diet, the differences in food intake might have produced differences in intraluminal gut chloride. It seems possible that these two sources of error, the one tending to give a falsely high value and the other a value falsely low, could balance out.

Chloride in cells of viscera exclusive of liver, brain, spleen and kidneys. Although chloride has been described as being intracellularly located in the pylorus, testes and lungs (2) the amounts present and their significance have not been clearly defined. The problem has been approached in the present study by determining the inulin, chloride and sodium spaces of gut, lung and testes after prolonged infusion of inulin. The data for these volumes are shown in Table IV. In this table the chloride and sodium spaces have been corrected for the amounts of these ions determined by

TABLE IV

Inulin and corrected chloride and sodium spaces of viscera after 6 and 24 hours of inulin infusion

\begin{tabular}{|c|c|c|c|c|c|c|c|}
\hline $\begin{array}{l}\text { Rat } \\
\text { no. }\end{array}$ & $\begin{array}{c}\text { Wt. of } \\
\text { viscera } \\
g m .\end{array}$ & $\begin{array}{l}\text { Inulin } \\
\text { space } \\
\text { ml. }\end{array}$ & $\frac{\text { Inulin sp. }}{\text { Viscera wt. }}$ & $\begin{array}{c}\text { Corrected } \\
\text { chloride } \\
\text { space } \\
\text { ml. }\end{array}$ & $\begin{array}{l}\text { Corrected } \\
\text { sodium } \\
\text { space } \\
\text { ml. }\end{array}$ & $\frac{\text { Inulin sp. }}{\mathrm{Cl} \text { space }}$ & $\frac{\text { Inulin sp. }}{\text { Na space }}$ \\
\hline \multicolumn{8}{|c|}{ After 6 hours of inulin infusion } \\
\hline $\begin{array}{r}2 \\
3 \\
4 \\
7 \\
10 \\
11 \\
12\end{array}$ & $\begin{array}{l}21.4 \\
21.0 \\
23.5 \\
22.1 \\
20.5 \\
21.1 \\
21.1\end{array}$ & $\begin{array}{l}5.35 \\
6.88 \\
7.23 \\
6.89 \\
6.56 \\
5.42 \\
6.26\end{array}$ & $\begin{array}{l}.25 \\
.33 \\
.31 \\
.31 \\
.32 \\
.26 \\
.30\end{array}$ & $\begin{array}{l}8.55 \\
6.21 \\
7.43 \\
8.62 \\
8.33 \\
6.57 \\
7.43\end{array}$ & $\begin{array}{l}5.23 \\
4.95 \\
6.16 \\
7.92 \\
6.73 \\
5.42 \\
5.91\end{array}$ & $\begin{array}{l}0.626 \\
1.11 \\
0.974 \\
0.80 \\
0.788 \\
8.826 \\
0.842\end{array}$ & $\begin{array}{l}1.02 \\
1.39 \\
1.17 \\
0.87 \\
0.97 \\
1.00 \\
1.06\end{array}$ \\
\hline \multicolumn{3}{|c|}{ Averages } & .29 & 7.59 & 6.04 & 0.852 & 1.07 \\
\hline \multicolumn{8}{|c|}{ After 24 hours of inulin infusion } \\
\hline $\begin{array}{r}5 \\
9 \\
13 \\
14\end{array}$ & $\begin{array}{l}22.6 \\
19.8 \\
23.7 \\
25.7\end{array}$ & $\begin{array}{l}6.11 \\
6.33 \\
9.93 \\
8.53\end{array}$ & $\begin{array}{l}.27 \\
.32 \\
.42 \\
.33\end{array}$ & $\begin{array}{l}7.38 \\
6.06 \\
9.23 \\
7.48\end{array}$ & $\begin{array}{l}6.89 \\
5.78 \\
6.30 \\
6.84\end{array}$ & $\begin{array}{l}0.828 \\
1.04 \\
1.076 \\
1.19\end{array}$ & $\begin{array}{l}0.89 \\
1.10 \\
1.57 \\
1.25\end{array}$ \\
\hline \multicolumn{3}{|c|}{$\begin{array}{l}\text { Averages } \\
\text { Averages (Both groups) }\end{array}$} & .33 & $\begin{array}{l}7.54 \\
7.57\end{array}$ & $\begin{array}{l}6.45 \\
6.19\end{array}$ & $\overline{1.021}$ & $\overline{1.20}$ \\
\hline
\end{tabular}


the flushing experiments (see above) to be present in the gut lumen. This correction amounted to $0.22 \mathrm{mEq}$. of chloride and $0.43 \mathrm{mEq}$. of sodium for the 300-gram rats used.

At the outset it should be emphasized that use of the inulin space measurement for determining the amounts of sodium and chloride within the cells is hazardous. Although the measurement of inulin space by tissue analysis for inulin precludes errors in space measurement due to metabolism of inulin, it does not preclude error resulting from sequestration of inulin by macrophages as recently suggested by White and Rolf (21). These authors found that tissues rich in macrophages gave impossibly high inulin space values. With this source of error in mind, the present data can probably be interpreted as reliably by simple comparison of sodium and chloride spaces as by resorting to inulin space measurement. It can be seen that in every specimen the corrected chloride space exceeded the corrected sodium space, the difference averaging $1.38 \mathrm{ml}$. Assuming no sodium to be present in the cells and the sodium space to equal extracellular volume, the greater chloride space would represent chloride within the cells. The volume of $1.38 \mathrm{ml}$. is equivalent to approximately $0.17 \mathrm{mEq}$. of chloride or, corrected to a 220 -gram rat, $0.12 \mathrm{mEq}$. In agreement with this interpretation is the inulin space at 6 hours. Inulin space at this time was in fair agreement with the sodium space but was smaller than the chloride space by 15 per cent. Taking the inulin space at 6 hours as approximating extracellular fluid volume, an intracellular chloride content similar to that defined above would be calculated. By this interpretation the further expansion of the inulin space at 24 hours to equality with the chloride space and to 33 per cent of the wet weight of the tissue would be ascribed to macrophage sequestration of inulin.

Disregarding the possibility of macrophage sequestration and using only the 24-hour values, the data could be alternatively interpreted as indicating that at 24 hours complete penetration of extracellular fluid by inulin had occurred. The identity of inulin and chloride spaces at this time would then indicate no chloride to be intracellular in viscera, a conclusion contrary to that of previous workers. Since this interpretation does not account for the smaller sodium space, the calcula- tion based on the sodium space, indicating that $0.12 \mathrm{mEq}$. of chloride is present intracellularly in viscera, seems more reasonable.

Estimation of chloride space. As may be seen in Table II the chloride which must be considered as outside the extracellular fluid amounts, in a 220 gram rat, to $0.85 \mathrm{mEq}$. or 12.7 per cent of body chloride. Of this non-extracellular chloride, the greatest amounts are found in the red cells and in the transcellular fluid in the lumen of the gastrointestinal tract. Because of the technical difficulties in assessing the position of chloride in brain, spleen and kidneys, these organs have not been included in the calculations. Their omission would appear to be of little consequence. In the rat the combined weight of these organs amounts to only 1.5 per cent of body weight and from the data of Manery and Hastings (2) it can be calculated that their chloride content amounts to only 2.2 per cent of total body chloride. Thus, even if a relatively large fraction of the chloride of these organs were intracellular it would constitute only a small fraction of the total body chloride.

For the 220-gram rat, the chloride in extracellular fluid amounts to $4.88 \mathrm{mEq}$. (Table II). The value for serum chloride concentration used in calculating the chloride space was determined by analysis of the sera of 37 normal rats. The average was $109.5 \mathrm{mEq}$. per $\mathrm{L}$. with a range from 105.6 to 113.6. Correcting the average value for serum water and for the Donnan factor gives a value of $124 \mathrm{mEq}$. per $\mathrm{L}$. for the serum ultrafiltrate concentration and a chloride space of $47.4 \mathrm{ml}$.

\section{Extracellular space calculated from extracellular sodium}

Extracellular sodium has been calculated as a means of verifying the accuracy of the extracellular volume predicted from the distribution of chloride. The calculated amounts of sodium in cells and bone in a 220-gram rat are shown in Table $\mathrm{V}$ and the calculations are described below.

Bone sodium. In five rats weighing approximately 220 grams the bone salt sodium: calcium ratio was found to average 0.0200 with a range of 0.0187 to 0.0205 (Table VI). Total bone calcium in a 220 -gram rat, calculated from the regression equation shown in Table I, amounts to $111.7 \mathrm{mEq}$. Multiplying the bone salt sodium: 


\section{TABLE $\nabla$}

Calculation of sodium in extracellular fluid and extracellular fluid volume of a 220-gram rat (50 gram FFDS)

\begin{tabular}{|c|c|c|}
\hline & $\underline{3}$ & $\begin{array}{l}\text { Porcent } \\
\text { of total }\end{array}$ \\
\hline \multicolumn{3}{|l|}{ Sodim Outside Extrecelluler Muid } \\
\hline $\begin{array}{l}\text { Bone galt oodium (rron Marce retio } \\
\text { for bono salt and total body can) }\end{array}$ & 2.22 & 20.2 \\
\hline 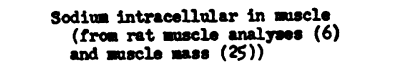 & 0.60 & 5.8 \\
\hline $\begin{array}{l}\text { Exthrocyto sodium (from sodive } \\
\text { concentration of rod cell metor } \\
\text { (8), blood rolum and howatocerit } \\
\text { (9), and rod cell wator content) }\end{array}$ & 0.24 & 1.3 \\
\hline $\begin{array}{l}\text { Sodive within lumon of gat } \\
\text { (dotorminod by nushing of gat) }\end{array}$ & 0.32 & 3.1 \\
\hline 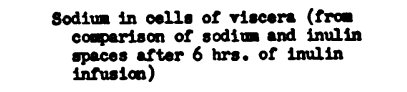 & $\underline{0}$ & 은 \\
\hline Sotal & 3.27 & 32.4 \\
\hline Total Body Sodive & 10.43 & \\
\hline Sodium in Extrecollular Muld & 7.26 & 68.6 \\
\hline
\end{tabular}

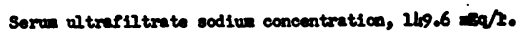

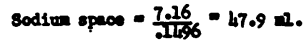

calcium ratio by total body calcium gave an average value of $2.21 \mathrm{mEq}$. for total bone salt sodium.

The accuracy of the estimate of the bone salt sodium is of importance in the assessment of electrolyte distribution because of the large fraction of body sodium present in bone. Possible sources of error lie in the method of estimation of the sodium: calcium ratio and in the assumption inherent in the calculation that the sodium: calcium ratio of all bones is the same as that of the specimens of bone taken for analysis. ${ }^{2}$ The general agreement of the sodium:calcium ratio of 0.0200 obtained in the present study with that of 0.0206 obtained by Bergstrom (22) by flame photometric determination of sodium suggests the absence of gross errors in analysis. The validity of the assumption that all bones have the same

\footnotetext{
2 Knowing the weights and calcium content of the bone samples taken for analysis and the total body calcium, the fraction of total skeleton represented by the bone samples may be calculated. The bone sample weights in terms of fat free dry solid averaged 1.45 grams and their calcium content averaged $10.7 \mathrm{mEq}$. per gram FFDS. With an average total body calcium content in a 220-gram rat of $111.7 \mathrm{mEq}$. the total skeleton as FFDS may be calculated from the above as weighing 10.4 grams. The bone samples then represented on the average 14 per cent of the total skeleton.
}

sodium: calcium ratio is more difficult to assess. From fragmentary data, however, the assumption in the main appears to be correct. Agna and Knowles (23) have found in nine human subjects that rib and iliac crest are almost identical in their sodium: calcium ratios. On the other hand, the skull contained an average of 7 per cent more sodium per unit of calcium than did rib or ilium. Appendicular skeleton was not analyzed. ${ }^{3}$

Muscle cell sodium. Based on the data for muscle analyses of 13 rats by Cotlove, Holliday, Schwartz, and Wallace (6) the sodium intracellular in muscle was taken as $0.6 \mathrm{mEq}$. per 100 grams of fat free tissue. The muscle mass of the rat was taken from the data of Caster, Poncelet, Simon, and Armstrong (25). These authors were able to measure not only the muscle mass that was easily dissected from the skeleton but also the fraction adhering after dissection. The latter fraction was determined either from the composition of the ash or from the determination of actomyosin. The muscle mass of 320 to 350 -gram rats of good nutritional status was found by these authors to average 45.5 per cent of body weight. In a 220-gram rat the muscle mass would closely approximate 100 grams and would contain 0.6 mEq. per L. sodium in the intracellular space.

Erythrocyte sodium. After Bernstein (8), the sodium concentration of red cell water is taken as $28 \mathrm{mEq}$. per $\mathrm{L}$. The value of $0.14 \mathrm{mEq}$. for total red cell sodium was calculated in the manner described for erythrocyte chloride.

Sodium in lumen of the gastrointestinal tract. The quantity of sodium in the transcellular fluid in the gastrointestinal tract was determined as for chloride by the flushing procedure. The sodium recovered averaged $0.43 \mathrm{mEq}$. with the range of 0.35 to 0.50 . The amount in the 220 -gram rat

8 If in the rat the sodium: calcium ratio of the skull were greater than the rest of the skeleton by 5 per cent as appears to be the case in the human, the error resulting from neglect of this discrepancy in the present calculations would be minimal. The dried skull of a 220-gram rat weighs 1.42 grams (24). Assuming the calcium content of dried skull to be $10.7 \mathrm{mEq}$. per gram and a 5 per cent greater sodium:calcium ratio for skull, the bone sodium would be greater than that found in the present calculation by $0.015 \mathrm{mEq}$. This amount represents 0.02 per cent of the total body sodium. 
TABLE VI

Average values and range for bone calcium, sodium and chloride content and the bone salt sodium : bone calcium ratio

\begin{tabular}{ccccccc}
\hline \hline $\begin{array}{c}\text { No. of } \\
\text { rats }\end{array}$ & $\begin{array}{c}\text { Sodium } \\
m E q . / 100 \mathrm{gm} . \\
F F D S\end{array}$ & $\begin{array}{c}\text { Calcium } \\
m E q . / 100 \mathrm{gm} . \\
F F D S\end{array}$ & $\begin{array}{c}\text { Chloride } \\
m E q . / 100 \mathrm{gm} . \\
F F D S\end{array}$ & $\begin{array}{c}\text { Chloride } \\
\text { space } \\
m l .100 \mathrm{gm} . \\
F F D S\end{array}$ & $\begin{array}{c}\text { Sodium in } \\
\text { chloride } \\
\text { space } \\
m E q .100 \mathrm{gm} . \\
\text { FFDS }\end{array}$ & $\begin{array}{c}\text { Bone salt sodium } \\
\text { Bone calcium }\end{array}$ \\
\hline 5 & $\begin{array}{c}29.7 \\
32.8-26.7\end{array}$ & $\begin{array}{c}1,074.4 \\
1,032-1,109\end{array}$ & $\begin{array}{c}6.83 \\
8.65-5.23\end{array}$ & 55.1 & 8.23 & 0.0200 \\
\hline
\end{tabular}

would be $0.32 \mathrm{mEq}$. or slightly more than 3 per cent of total body sodium.

Sodium intracellular in viscera. As mentioned above the liver was considered to contain no intracellular sodium; the volume of distribution of this ion was considered as a measure of the extracellular space. In the rest of the viscera studied (lungs, gastrointestinal tract and testes) the comparison of the inulin with the sodium space was used to assess the amount of sodium located intracellularly. For the comparison, the sodium space was corrected for the amount of sodium found by the flushing procedure to be present in the gut lumen. The correction amounted to 0.43 $\mathrm{mEq}$. As may be seen in Table IV the inulin space approximates the corrected sodium space after six hours of inulin infusion. The data have been interpreted to indicate that no sodium is present within the cells of the viscera.

Estimation of extracellular sodium space. Summing up these corrections in Table $\mathrm{V}$, it is seen that the sodium outside the extracellular space in a 220 -gram rat would be $3.27 \mathrm{mEq}$. or 31.4 per cent of total body sodium.

For calculation of the extracellular sodium space, the value for extracellular sodium (7.16 mEq.) has been divided by the average sodium concentration in a serum ultrafiltrate. Serum sodium concentration in 15 normal rats averaged $146.7 \mathrm{mEq}$. per L. and the calculated serum ultrafiltrate concentration, $149.6 \mathrm{mEq}$. per L. The resultant extracellular sodium space of $47.9 \mathrm{ml}$. is in good agreement with the extracellular chloride space of $47.4 \mathrm{ml}$.

Partitioning of body water, sodium, and potassium. Total body water in a 220 -gram rat averaged $149.4 \mathrm{ml}$. (Table I). Assuming extracellular volume as $48 \mathrm{ml}$. the extracellular phase would constitute 32 per cent of total body water or 21.8 per cent of body weight.
The partitioning of sodium in the body and the net concentrations of body sodium, potassium and magnesium in intracellular water are shown in Figure 1. For the calculation of intracellular volume, the volume of fluid within the gut was determined on six rats of 220 -gram weight. The average value was $3.6 \pm 0.42(\mathrm{SD}) \mathrm{ml}$. Subtracting this value and that of $48 \mathrm{ml}$. for extracellular volume from total body water gives $97.8 \mathrm{ml}$. for the volume of intracellular water. Extracellular potassium in a 220 -gram rat was calculated as 0.19 $\mathrm{mEq}$. The net concentration of potassium in cell water calculated as shown in Figure 1, would be $146 \mathrm{mEq}$. per liter. Sodium concentration in cell water, similarly calculated, would be $7.4 \mathrm{mEq}$. per liter.

For the calculation of the magnesium concentration of cell water the data of Duckworth, Godden, and Warnock (26) have been used. These authors found the calcium: magnesium ratio of rat bone to be 41.8. From this ratio and from total body calcium it may be calculated that 2.68 $\mathrm{mEq}$. of magnesium are in the bones of a 220-gram

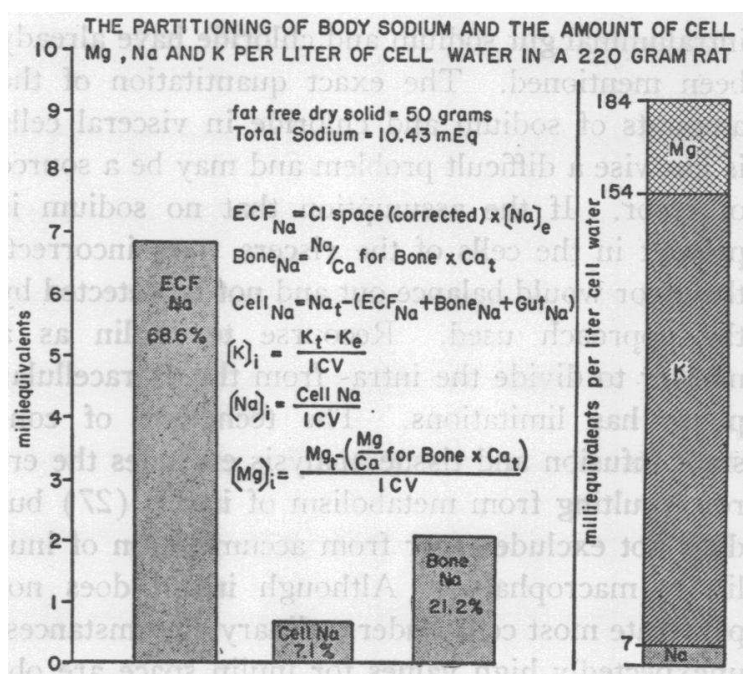

Fig. 1. 
rat, leaving $3 \mathrm{mEq}$. in the soft tissues. Neglecting extracellular magnesium the cell water concentration of magnesium would be $30 \mathrm{mEq}$. per liter. This value agrees well with that of $33 \mathrm{mEq}$. per liter found by other investigators (6) for the magnesium concentration of muscle cell water. Similarly, from the calcium : phosphorus ratio for bone (26) and from total body calcium it can be calculated that $35.3 \mathrm{mMols}$ of phosphorus (or 83 per cent of total body phosphorus) are present in bone.

\section{DISCUSSION}

For the precise interpretation of change in intracellular electrolyte during metabolic studies and for the proper partitioning of electrolyte in the body it is desirable that extracellular and intracellular volumes be defined. The present study has approached the problem of volume measurement by determining extracellular volume from extracellular chloride. An attempt has been made to verify the result by demonstrating that the sodium content of this extracellular volume corresponds in amount with that calculated from total body sodium minus the amounts present in bone and in cells. The good agreement of these independent approaches strongly suggests that extracellular volume has been correctly measured.

In spite of the good agreement, it should in all fairness be pointed out that errors could still exist which, if present on both the sodium and chloride sides of the balance, would cancel out. Possible errors in the assessment of bone sodium and of intraluminal gut sodium and chloride have already been mentioned. The exact quantitation of the amounts of sodium and chloride in visceral cells is likewise a difficult problem and may be a source of error. If the assumption that no sodium is present in the cells of the viscera were incorrect, the error would balance out and not be detected by the approach used. Recourse to inulin as a marker to divide the intra- from the extracellular phase has limitations. The technique of constant infusion and tissue analysis excludes the error resulting from metabolism of inulin (27) but does not exclude error from accumulation of inulin in macrophages. Although inulin does not penetrate most cells under ordinary circumstances, unexpectedly high values for inulin space are obtained in anuric patients (28) and in nephrecto- mized rats (21). Under conditions of nephrectomy, many substances normally extracellular in distribution predict volumes which are unreasonably high (29) and the possibility cannot be excluded that under these conditions ions or molecules penetrate the cellular phase. White and Rolf (21) using the nephrectomized rat and tissue analysis for inulin obtained a progressively large inulin space which, after 72 hours, predicted volumes exceeding total body water. Such findings may be related in some way to the removal of renal tissue, for the inulin space of rat muscle was significantly higher than that demonstrated by Cotlove (7) in animals with intact kidneys constantly infused with inulin. In White and Rolf's study (21), however, the anomaly was greatest in tissues rich in macrophages, such as liver, and the authors suggest that sequestration of inulin can occur in macrophage cells. In the non-nephrectomized animals in the present study it was found that in liver, the inulin space greatly exceeded both the sodium and chloride spaces after 24 hours of infusion. Hence, absence of renal tissue appears not to be the sole factor responsible for the large inulin spaces of nephrectomized animals. Whether in the other viscera studied, macrophage sequestration of inulin accounted for the increase in inulin space relative to sodium space as the inulin infusion was prolonged to 24 hours (Table IV) cannot be determined. This interpretation seems the most plausible, however, when the data are considered from all aspects, and the use of the six-hour inulin space, or the closely similar sodium space, as an approximation of extracellular volume appears to be justified.

A further source of error lies in the estimation of the "excess" chloride of connective tissue. It should be noted that the calculations assume that all of body collagen has an affinity for "excess" chloride equal to that of the large tendon masses taken for analysis. This assumption is probably in the main correct, as pointed out by Manery, Danielson, and Hastings (1), insofar as the connective tissue of muscle, which accounts for the majority of body collagen, is a direct extension of and probably similar in structure to tendon. However, the collagen of bone matrix and in visceral organs could well differ from tendon in its affinity for chloride. Also the wide differences in the amount of excess chloride in connective tissue 
found by various investigators should be borne in mind. Manery, Danielson, and Hastings (1) found the chloride concentration of connective tissue water in rabbits to average $8.4 \mathrm{mEq}$. per $\mathrm{L}$. greater than the concentration in a serum ultrafiltrate, a value in good agreement with that of 6 $\mathrm{mEq}$. per L. found in the present study. On the other hand, another group of workers (30) found the concentration in dogs to be approximately equal to that of a serum ultrafiltrate while more recently a concentration in connective tissue water greater by $56 \mathrm{mEq}$. per L. than that of the serum ultrafiltrate has been reported in rats (31). It is possible that some of these differences are attributable to difficulties inherent in the methods of chloride analysis (4); the loss of variable amounts of water at the time of dissection would appear not to be the sole responsible factor.

While it is obvious from the above that errors may be present, most of them would appear to be of relatively little significance to the present study. As it stands, the study predicts that 87 per cent of total body chloride is in the extracellular fluid. Of the 13 per cent located outside of this compartment, more than half is in the erythrocytes and in the gastrointestinal tract. Because the amounts in cells and "excess" in connective tissue are so small, even gross errors in the quantitation of these fractions would have little effect on the overall assessment. For example, doubling the amount of "excess" chloride associated with connective tissue would reduce the present estimate of extracellular chloride by only 1.5 per cent. The conclusion that most of body chloride is in extracellular fluid appears justified. The data do not support the contention of other investigators employing differing techniques (32, 33 ) that 30 per cent or more of body chloride resides outside the extracellular fluid.

Previously, Manery and Hastings (2), Manery and Haege (34) and Amberson, Nash, Mulder, and Binns (35) have produced considerable evidence for the contention that chloride is predominantly extracellular in various tissues. At the same time these studies have suggested that intracellular chloride exists in pyloric tissue, stomach fundus and testes.

It would seem of importance that the exchangeable chloride of the rat measured with bromide over a 3-hour period closely predicts the true carcass chloride (4). A corollary of the findings presented is that the bromide or radio chloride space corrected for red cell bromide or chloride gives a close approximation of all phases of the extracellular fluid volume in the normal subject.

The value of $146 \mathrm{mEq}$. per L. obtained in the present study for the potassium concentration of cell water agrees well with the value of $140 \mathrm{mEq}$. per L. obtained by Harrison, Darrow, and Yannet (36) for the dog by carcass analysis using the uncorrected chloride space as the measure of extracellular volume. By indirect methods, however, widely diverging values have been obtained. Using inulin, $\mathrm{D}_{2} \mathrm{O}, \mathrm{K}^{42}$ and $\mathrm{Na}^{24}$ the intracellular potassium and sodium concentration of the dog averaged 115 and $35 \mathrm{mEq}$. per liter of cell water, respectively (37). These concentrations are greater for sodium and lower for potassium, when comparison is made with the present data. Possibly inulin under the conditions of these dog experiments under-estimates the total extracellular volume (38). Moore (39) using thiocyanate as a measure of extracellular volume and $\mathrm{D}_{2} \mathrm{O}, \mathrm{K}^{42}$ and $\mathrm{Na}^{24}$ to measure total water, exchangeable potassium and sodium, respectively, predicted in man an intracellular potassium concentration of $163 \mathrm{mEq}$. per liter of cell water. No estimate of transcellular fluid was possible in this study. This potassium concentration would seem to be high as a result of the fact that thiocyanate over-estimates the extracellular space $(40,41)$.

Evidence is at hand that intracellular and extracellular osmolar concentrations in the rat are equal (42). There is also some evidence that the major fraction of the magnesium of intracellular fluid is not dissociated $(43,44)$ and is probably bound to protein and phosphate anions (44) so that almost all of the intracellular potassium should be osmotically active. However, Macallum demonstrated more than 50 years ago (45) that while most of the potassium of the cell is evenly distributed throughout the cytoplasm, local points of high concentration can be detected. More modern investigations (46) suggest that about 13 per cent of cell potassium is not osmotically active and is present in mitochondria. The present study does not allow conclusions regarding the tonicity of cell fluid. 


\section{SUM MARY}

An attempt has been made to determine the amount of sodium and chloride in the extracellular fluid in the rat by correcting total body sodium and chloride for the amounts of these ions which are outside the extracellular fluid. Corrections for chloride included the "excess" chloride of connective tissue calculated from total body collagen and the results of tendon analysis, chloride intracellular in liver calculated from the sodium space of liver, and chloride in the lumen of the gut determined from analysis of gut contents. Erythrocyte chloride was calculated from data in the literature. The intracellular chloride of the respiratory and gastrointestinal tracts and in the testes was assessed by tissue analysis after the constant infusion of inulin. From data of other investigators, it was concluded that no chloride is present intracellularly in muscle.

It was found that 87.3 per cent of body chloride can be considered as present in extracellular fluid. The chloride in erythrocytes and in the gut lumen, representing 6.1 and 2.4 per cent of total body chloride, respectively, account for the bulk of the non-extracellular chloride.

To obtain extracellular sodium, total body sodium was corrected for bone salt sodium, calculated as the product of the $\mathrm{Na} / \mathrm{Ca}$ ratio for bone and total body calcium, and for sodium in the lumen of the gut, determined from the analysis of gut contents. Data in the literature were used for the calculation of erythrocyte sodium and for the intracellular sodium of muscle.

For a 220-gram rat, extracellular fluid volume calculated from chloride was found to be $47.4 \mathrm{ml}$. as compared with $47.9 \mathrm{ml}$. calculated from sodium. The good agreement between these values suggests that this approach and the corrections used are valid. Extracellular volume would thus represent 21.8 per cent of body weight or 32 per cent of body water.

From the data for extracellular volume and from other parameters of body composition obtained from carcass analysis and from the literature, the theoretical net concentrations of potassium, sodium and magnesium in cell water have been calculated.

\section{REFERENCES}

1. Manery, J. F., Danielson, I. S., and Hastings, A. B., Connective tissue electrolytes. J. Biol. Chem., 1938, 124, 359.

2. Manery, J. F., and Hastings, A. B., The distribution of electrolytes in mammalian tissues. J. Biol. Chem., 1939, 127, 657.

3. Nichols, G., Jr., Nichols, N., Weil, W. B., and Wallace, W. M., The direct measurement of the extracellular phase of tissues. J. Clin. Invest., 1953, 32, 1299.

4. Cheek, D. B., and West, C. D., An appraisal of methods of tissue chloride analysis: the total carcass chloride, exchangeable chloride, potassium and water of the rat. J. Clin. Invest., 1955, 34, 1744.

5. Cheek, D. B., and West, C. D., Alterations in body composition with sodium loading and potassium restriction in the rat: the total body sodium, nitrogen, magnesium and calcium. J. Clin. Invest., 1956, 35, 763.

6. Cotlove, E., Holliday, M. A., Schwartz, R., and Wallace, W. M., Effects of electrolyte depletion and acid-base disturbance on muscle cations. Am. J. Physiol., 1951, 167, 665.

7. Cotlove, E., Mechanism and extent of distribution of inulin and sucrose in chloride space of tissues. Am. J. Physiol., 1954, 176, 396.

8. Bernstein, R. E., Potassium and sodium balance in mammalian red cells. Science, 1954, 120, 459.

9. Wang, C. F., and Hegsted, D. M., Normal blood volume, plasma volume and thiocyanate space in rats and their relation to body weight. Am. J. Physiol., 1949, 156, 218.

10. Consolazio, W. V., and Talbott, J. H., Modification of the method of Shohl and Bennett for the determination of potassium in serum and urine. J. Biol. Chem., 1938, 126, 55.

11. Cheek, D. B., and Golden, C. C., Total body potassium in the rat: gravimetric determination as compared with flame photometry. In manuscript.

12. Butler, A. M., and Tuthill, E., An application of the uranyl zinc acetate method for determination of sodium in biological material. J. Biol. Chem., 1931, 93, 171.

13. Edelman, I. S., James, A. H., Baden, H., and Moore, F. D., Electrolyte composition of bone and the penetration of radiosodium and deuterium oxide into dog and human bone. J. Clin. Invest., 1954, 33, 122.

14. Spencer, H. C., Morgulis, S., and Wilder, V. M., A micromethod for the determination of gelatin and a study of the collagen content of muscles from normal and dystrophic rabbits. J. Biol. Chem., 1937, 120, 257.

15. Kellogg, R. H., Burack, W. R., and Isselbacher, K J., Comparison of diuresis produced by isotonic saline solutions and by water in rats studied by a 
"steady state" method. Am. J. Physiol., 1954, 177, 27.

16. Schreiner, G. E., Determination of inulin by means of resorcinol. Proc. Soc. Exper. Biol. \& Med., 1950, 74, 117.

17. Ross, G., and Mokotoff, R., Determination of inulin in muscle. J. Biol. Chem., 1951, 190, 659.

18. Conway, E. J., Microdiffusion Analysis and Volumetric Error. 2nd ed., London, C. Lockwood, 1950, Chap. 23 and 24.

19. Van Slyke, D. D., The determination of chlorides in blood and tissues. J. Biol. Chem., 1923, 58, 523.

20. White, H. L., and Rolf, D., Whole tissue electrolyte analyses in normal and adrenalectomized rats. Am. J. Physiol., 1955, 180, 287.

21. White, H. L., and Rolf, D., Inulin space as a function of equilibration time. Am. J. Physiol., 1956, $185,152$.

22. Bergstrom, W. H., The participation of bone in total body sodium metabolism in the rat. J. Clin. Invest., 1955, 34, 997.

23. Agna, J. W., and Knowles, H. C., Jr., Personal communication.

24. Donaldson, H. H., Ed., The Rat; Data and Reference Tables for the Albino Rat (Mus norvegicus albinus) and the Norway Rat (Mus norvegicus). 2nd ed., rev., Philadelphia, 1924 (Memoirs of the Wistar Institute of Anatomy and Biology, No. 6).

25. Caster, W. O., Poncelet, J., Simon, A. B., and Armstrong, W. D., Tissue weights of the rat. I. Normal values determined by dissection and chemical methods. Proc. Soc. Exper. Biol. \& Med., 1956, 91, 122.

26. Duckworth, J., Godden, W., and Warnock, G. M., The effect of acute magnesium deficiency on bone formation in rats. Biochem. J., 1940, 34, 97.

27. Deane, N., and Smith, H. W., Fate of inulin and sucrose in normal subjects as determined by a urine reinfusion technique. J. Clin. Invest., 1955, 34, 681.

28. Finkenstaedt, J. T., O’Meara, M. P., and Merrill, J. P., Failure of equilibration of inulin in anuric subjects. J. Clin. Invest., 1952, 31, 627.

29. McDonald, I. R., Coats, D. A., and Munro, J., Body water and electrolyte changes in bilaterally nephrectomized sheep. Australian J. Exper. Biol. \& M. Sc., 1954, 32, 275.

30. Muntwyler, E., Mellors, R. C., Mautz, F. R., and Mangun, G. H., Electrolyte and water equilibria in the dog. III. Electrolyte and water exchange between tendon and blood. J. Biol. Chem., 1940, 134, 389.
31. Levitt, M. F., Turner, L. B., Sweet, A. Y., and Pandiri, D., The response of bone, connective tissue, and muscle to acute acidosis. J. Clin. Invest., 1956, 35, 98.

32. Deane, N., Ziff, M., and Smith, H. W., The distribution of total body chloride in man. J. Clin. Invest., 1952, 31, 200.

33. Burch, G. E., Threefoot, S. A., and Ray, C. T., Rates of turnover and biologic decay of chloride and chloride space in the dog determined with the long-life isotope, $\mathrm{Cl}^{20}$. J. Lab. \& Clin. Med., 1950, 35, 331.

34. Manery, J. F., and Haege, L. F., The extent to which radioactive chloride penetrates tissues, and its significance. Am. J. Physiol., 1941, 134, 83.

35. Amberson, W. R., Nash, T. P., Mulder, A. G., and Binns, D., The relationship between tissue chloride and plasma chloride. Am. J. Physiol., 1938, 122, 224.

36. Harrison, H. E., Darrow, D. C., and Yannet, H., The total electrolyte content of animals and its probable relation to the distribution of body water. J. Biol. Chem., 1936, 113, 515.

37. Levitt, M. F., and Gaudino, M., Use of radioactive isotopes to measure intracellular cation concentrations in the normal dog. Am. J. Physiol., 1949, 159, 67.

38. Swan, R. C., Madisso, H., and Pitts, R. F., Measurement of extracellular fluid volume in nephrectomized dogs. J. Clin. Invest., 1954, 33, 1447.

39. Moore, F. D., Determination of total body water and solids with isotopes. Science, 1946, 104, 157.

40. Wilde, W. S., The chloride equilibrium in muscle. Am. J. Physiol., 1945, 143, 666.

41. Overman, R. R., Davis, A. K., and Tharp, E., Blood and "extracellular" fluid volumes and ionic balance in human therapeutic malaria. Federation Proc., 1947, 6, 174.

42. Conway, E. J., and McCormack, J. I., The total intracellular concentration of mammalian tissues compared with that of the extracellular fluid. J. Physiol., 1953, 120, 1.

43. Conway, E. J., and Cruess-Callaghan, G., Magnesium and chloride "permeations" in muscle. Biochem. J., 1937, 31, 828.

44. Tabor, H., and Hastings, A. B., The ionization constant of secondary magnesium phosphate. J. Biol. Chem., 1948, 148, 627

45. Macallum, A. B., On the distribution of potassium in animal and vegetable cells. J. Physiol., 1905, 32, 95.

46. Holland, W. C., and Auditore, G. V., Distribution of potassium in liver, kidney and brain of the rat and guinea pig. Am. J. Physiol., 1955, 183, 309. 